\title{
"This Is Our Music": Italian Teen Pop Press and Genres in the 1960s
}

\author{
Jacopo Tomatis \\ Università degli Studi di Torino \\ jacopo.tomatis@unito.it
}

\begin{abstract}
Popular music studies rarely consider genres as cultural concepts both historically and socially contingent. From a diachronic perspective, music journalistic discourse can be used to examine how music categories are created, named and negotiated between music industry, musicians, critics and fans, either for practical or aesthetic purposes. Italian teen pop magazines in the mid1960s provide a valuable case study. This article will focus on two Italian teen publications, Ciao amici and Big, between 1964 and 1967, and will connect the rhetoric they used to the rise of youth community in the same period. The genre of musica nostra (music of our own) was introduced to describe the music teenagers were listening to, and suggested the pride of belonging to a community of peers. In the last section I will outline how such an ideology of youth community was connected to authenticity and to specific aesthetic values.
\end{abstract}

Keywords: teen pop press, Italian popular music, authenticity, genres, 1960s

\section{Introduction: genres, communities and music press}

Genres and categories have a paramount role in music discourse, in everyday discussions, academic publications and journalistic writings. The anthropologist Steven Feld (1984: 1), following Charles Seeger's reflections on music and speech (1977), claims that questioning "what does music communicate?" also means questioning "what does speech about music communicate?". Since most discourses about music deal with categories, either for practical or aesthetic purposes, genres are a part of human relations with music.

Franco Fabbri (2012: 188) describes a music genre as "a set of music events regulated by conventions accepted by a community". Still, we should ask what does 'community' mean: Kaufman Shelemay (2011: 349 passim) provides an outline of the evolution of the concept of 'community' in music scholarship: such a concept - she states - has achieved a status across disciplines as a "keyword" which "organizes knowledge" in many ways. As a consequence, the term became "so ambiguous that to use [it] is to be confronted with the necessity to argue for its use" (ibid.: 359). From Fabbri's perspective (2012), "conventions" defining a genre organize musical practices, meanings and values. Since these are not given a priori, but constructed through interpretive processes, we can thus assume that a community shares at least the same interpretive strategies.

The concept of "interpretive community" was introduced in literary studies by Stanley Fish (1980: 14), who stated that "interpretive communities are made up of those who share interpretive strategies not for reading but for writing texts, for constituting their 
properties" (emphasis mine). ${ }^{1}$ Therefore, interpretive communities both define and are defined by music genres.

Conventions defining a genre can be structured by ideologies: the "ideology" of a genre can thus be seen as a "hyper-code", regulating the hierarchy among other codes (Fabbri 1982). Hence, ideology should be considered as a function of interpretive communities, and overlaps the concept of interpretive strategy. Communities are thus based on shared ideologies. The way the members of a community make sense of such a sharing from their internal point of view is crucial: in Kaufman Shelemay's terms (2011: 365), "a musical community is a social entity [...] rendering those who participate in making or listening to music aware of a connection among themselves".

As cultural concepts defined within and by a community, music genres are therefore both socially and historically contingent, and need to be studied from a diachronic perspective. Nevertheless, both music fans and critics usually conceive genres as assertive, timeless categories. Academic discourse tends to consider the genre system as a socially-negotiated taxonomy rather than to analyse it in its historical development, or within its specific cultural background. As an example, it is normally assumed that some globalised genres (as rock or beat) must be the same in all countries. Since genres are socially contingent, they must be set in their context: national 'translations' of international genres deserve specific attention, encompassing both the models and the different cultural context in which they later develop. ${ }^{2}$

Rick Altman's methodological suggestions for the study of media history seem to be suitable for the purpose of considering genres from a historical and cultural perspective. Altman (2004: 15) considers "representational technologies" not as "permanent fact[s] of life", but as cultural concepts, or "complex cultural signs", and therefore both socially and historically contingent. As Altman claims (2004: 18), "we must base our corpus not just on today's notion of the phenomenon under study, but also on contemporary understandings". Since genres are "complex cultural signs", we must consider their reception as a developing process.

As stated by Fabbri (2012: 187), among all the conventions that define a music genre, "naming conventions" deserve special attention. Different languages can thus affect the way a community defines and perceive a genre. ${ }^{3}$ For Altman (2004: 16), the process of naming a concept is "one of culture's most powerful forms of appropriation": cultural concepts begin their life with "multiple monikers" and "multiple identities" (ibid.). Therefore, historians are not supposed to look for the "birth" of a cultural concept. They will rather find a "crisis of identity" to investigate (ibid.).

Hence, in researching music communities and genres, popular music historians should ask, among other questions, 1) how people - or specific communities classified music in a given period and place, and which tags they used; 2) which kind of language different music communities used to talk about different genres; 3 ) which ideologies structured music values and meanings, and how music aesthetics developed accordingly, in relation to genres. Music publications and the categories they used to organize music, in their diachronic development, provide a valuable frame of research to answer these questions.

The protagonists of 1960s rock journalism in the UK "posit[ed] themselves as enlightened fans" (Gudmundsson et al. 2002: 60), sharing the same ideology of rock with their readers. Studies about popular music and the press have discussed the role of music fans as the "meaning-makers of popular music" (Atton 2009: 53) at least since Simon Frith's Sociology of Rock (1978). The contents of press coverage are thus usually considered as the outcome of a negotiation between journalists and readers, at least, with a proactive influence of the recording industry. Music fans and critics are hence part of the same interpretive community, sharing ideologies on music.

Studies focusing on the music press in the UK and the US in the 1960s (Atton 2009; Frith 1983; Toynbee 1993) highlighted the trajectory of rock criticism from the 
underground to the mainstream (as noticed by Bratus 2012), or from "gossip" to proper criticism (Gudmundsson et al. 2002: 41). Both accounts suggest the struggle for cultural accreditation of rock criticism, as well as for the recognition of rock as art. As might be expected, the two processes went on side by side, in a reciprocal feedback. As Frith (1983: 169) states, "underground papers were important as the source of what became the dominant ideology of rock". The attempts to describe rock (and rock criticism) in the Bourdieuian terms of a "semi-autonomous [...] field of cultural production" (Gudmundsson et al. 2002; Lindberg et al. 2005) seem to be coherent with this approach: authenticity is the key concept on which people measure the value of both popular music and popular music journalism. ${ }^{4}$ As a consequence, most studies on the music press have focused on fanzines and underground press, or on iconic magazines like NME or Rolling Stone, and have disregarded the role of teen pop magazines and popular tabloids. Furthermore, among the different journalistic genres, 'proper' critical writings - like record reviews - have deserved more attention than press releases, advice columns, advertisements or even interviews. ${ }^{5}$ In Italy too, some accounts of the development of the Italian music press have diminished the role of teen pop magazines. Max Stefani, founder of II Mucchio Selvaggio, one of the most prominent rock music magazines in Italy since the late 1970 s, denied any influence of 1960 s teen pop press on later music magazines, and praised instead the pioneering role of the first fanzines (Profane n.d.).

Yet, following Altman's suggestions, we should consider music in its "contemporary understandings" (2004: 18). Therefore, the impact of popular magazines on people's reception of music should not be ignored. As the title of my article indicates, I limit my inquiry to Italian teen pop press between 1964 and 1967, following the framework provided by the questions I previously posed. In the next section I provide an overview of the genres of young people's music in Italy in the 1960s, focusing on genre tags. I then examine in depth the tag musica nostra and its relation with youth community. Then, I analyse how teen pop magazines consolidated a community feeling through the innovative language, style and rhetoric they introduced; finally, the ideology of youth community, and the related concept of musica nostra, are connected to aesthetic values.

\section{Music genres and teen pop press in the 1960s}

The import of American rock and roll into Italy dates back to the early 1950s, when some international record companies opened their Italian branches. Yet, regardless of the increasing American influence, Italian popular music of the 1950s did not break the continuity with that of the 1930s and 1940s. Many lyricists and composers who were active during the Fascist period remained in full swing. Songs were usually standardized in structure and contents, and typically explored escapism; lyrics were written in a highly rhetorical style, and sung with operatic vocality. The Sanremo Festival, set in 1951, became the iconic place to hear this kind of traditional and conservative canzone (song), and the "benchmark for all Italian popular music" (Agostini 2007: 389).

A category of teenagers with specific tastes developed later than in other countries. As recalled by Alessandro Portelli (1978), the early discovery of American rock and roll in the 1950s was mainly a high- and middle-class phenomenon, and involved an 'intermediate' generation which was too young during the Resistance movement in World War II, and too old for attending the student demonstrations in 1968. Italian media described the rising youth culture in the late 1950s through two key themes: deviant behaviours of teenagers, and their new attitude towards consumer goods, mostly based on American models (Gorgolini 2004: 219). Only at the end of the decade, and especially after the so-called 'economic boom' in the early 1960s, did the Italian recording industry finally set off, and started targeting young listeners. Between 1959 and 1960 a new film genre appeared: the so-called musicarello. Italian movies of the 1950s had already treated teenagers' problems, but the new musicarelli were exclusively intended to entertain young people and to suit their tastes. The musicarelli consisted of a series of 
musical numbers, featuring teen idols, singers and entertainers; the plot was weak, and tailored to the protagonists' public image and talent.

In the same years, two new music genres emerged: the urlatori (shouters) and the cantautori ('singer-songwriters': for a discussion of this term see Tomatis 2010 and 2013). In spite of the many differences between the two, music press and fans interpreted both genres as a challenge to the Italian old-style canzone establishment and to the Italian tradition of the melodia (melody). In December 1960, the popular magazine Sorrisi e canzoni promoted a 'referendum' to establish a simulated parliament of the Italian canzone. Different parties corresponded to different genres: unsurprisingly, the cantautori and the urlatori sat in the left wing of the 'assembly'.

The urlatori was the first genre for young people to be exploited by the Italian recording industry, at the end of the 1950s. While trying to imitate American rock and roll, the urlatori re-negotiated most of the conventions of the original genre. Alessandro Portelli (1978: 60) recalls his personal experience:

All this American music burst at once, without notice or distinctions of any kind. We lacked the means to recognize the different styles and traditions within the rock field. That music had no relevance with our cultural background (and therefore it was attractive). Furthermore, we got that already shaken-up, and packaged, and we could not trace its evolution and history. ${ }^{6}$

As an example, rock and roll's sexual meanings were removed, or rather recontextualised for a more conservative audience. The lack of information, some linguistic misunderstandings, as well as several American stereotypes - those mocked by Renato Carosone's song “Tu vuo' fa' l'Americano" (1956), and Alberto Sordi's movie Un Americano a Roma (1954) - succeeded in creating a weird musical hybrid.

Adriano Celentano, the most successful urlatore, provides a valuable example to illustrate this point. Before he reached success singing in Italian, he started as a Jerry Lewis impersonator and lookalike, and later moved to imitation of Elvis Presley (Simonetta 1966). As Fabbri notes (2009: 114), during the first stage of his career he seemed to imitate Jerry Lewis and Jerry Lee Lewis at the same time, and it is doubtful that he knew they were not the same person. In contrast to early American rock and roll stars, the original urlatori included female singers, such as the future diva of the Italian canzone, Mina.

This kind of confusion lasted for years. When the Beatles reached their success in Italy, beat music became widely popular among teenagers. ${ }^{7}$ Yet, the Italian meaning of 'beat' was slightly different from the English one, and somewhat vague: as stated by journalist Piero Vivarelli in a recent interview (Rotondi 2010), some English words were used without fully knowing their meaning. 'Beat', in particular, was employed as an adjective and applied to anything new and supposedly young: "musica beat, disco beat, moda beat, ragazza beat, ballo beat" (beat music, beat record, beat fashion, beat girl, beat dance; ibid.). Furthermore, the term often overlapped with 'beatnik', and was accordingly connected to the Beat Generation. In 1966, the popular teen pop magazine Big promoted a panel discussion about beat music with music professionals and musicians. The radio host Gianni Boncompagni tried to provide a formal definition of the beat genre:

Technically speaking, all music with a prevalence of downbeats is 'beat'. Rhythm \& blues, rock, folk-rock, and so on, they are beat. In Italy, in the common meaning, 'beat' means English music, 'english sound' [in English in the original text]. (Big 1967) ${ }^{8}$

Occasionally, 'beat' also overlapped with 'folk'. Around 1965, the concept of folk in Italy had two different understandings, which often got mixed up. On one side, 'folk' meant Italian folk music (musica popolare), and bore a political connotation. On the other, the term referred to English and American folksingers - namely Donovan, Dylan and their imitators - and also Italian ones. Later, around 1966, folk music became the new trend. The Italian recording industry started exploiting the tag 'folk' as a commercial label 
to launch some new bands and soloists. Some of them (for instance Luigi Tenco) were also labelled as 'beat', or 'cantautori', in the same period [see Figure 1].

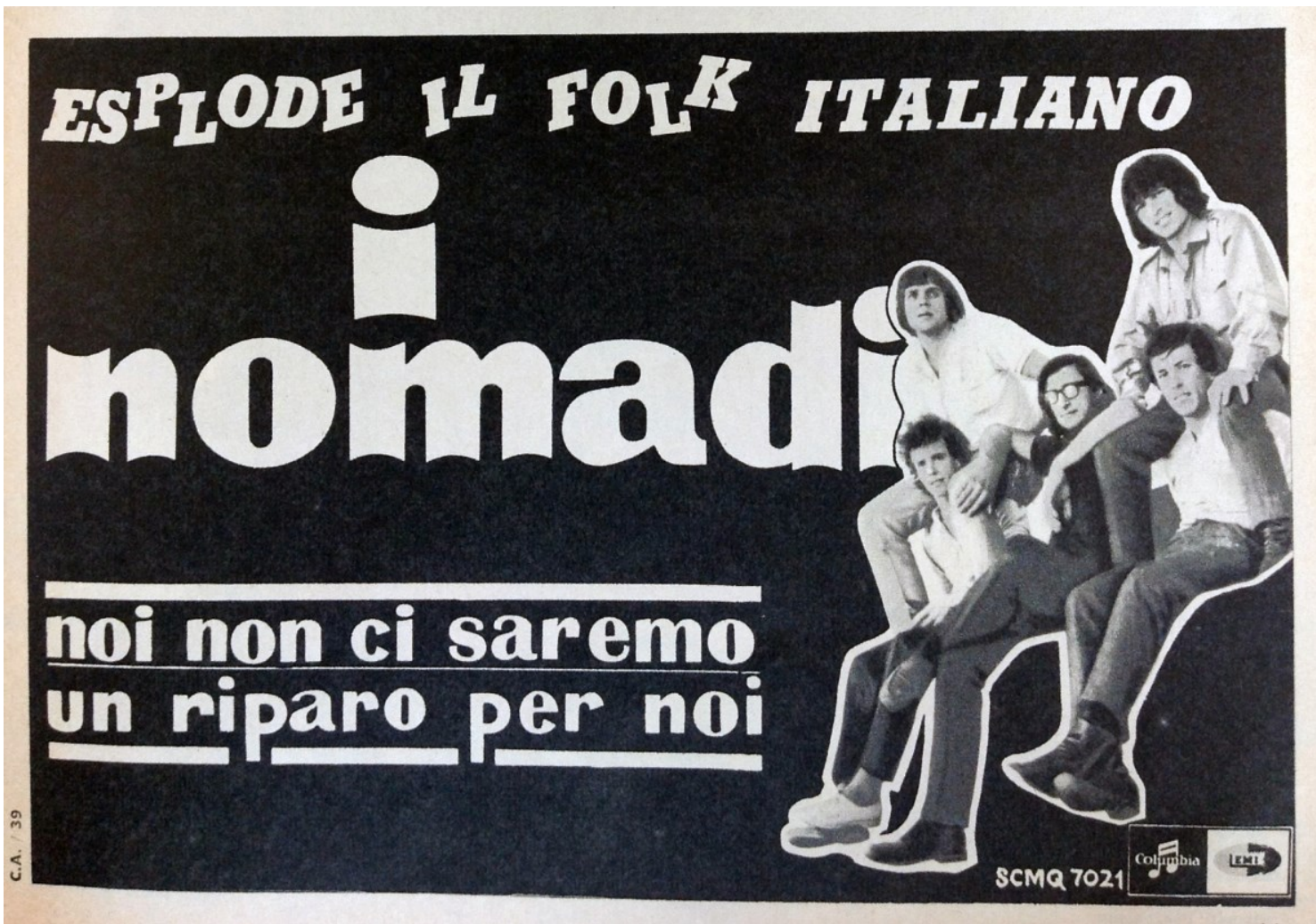

Figure 1: I Nomadi - "The outbreak of the Italian folk". Advertisement for Noi non ci saremo/ Un riparo per noi (Columbia 1966)

Press for teenagers developed a few years later than the music it was intended to cover. Still, in the early 1960s, several publications regarding popular music appeared in Italy. Among them we find the sophisticated magazine Discoteca - which featured a musica leggera (literally 'light music') section - and the trade paper Musica e dischi (a sort of Italian Billboard). Also, some popular illustrated weeklies such as /I Musichiere (connected to a TV show with the same name ${ }^{9}$ ) and Sorrisi e canzoni (founded in 1952) talked about popular music, and occasionally targeted young readers.

Yet Italy in the 1950s was for the most part still a rural country. In 1961, only 18 per cent of the population spoke Italian regularly (Rapini 2004: 100). The late development of teen pop press seems to be connected to the level of literacy, which has been improving since the early $1960 \mathrm{~s},{ }^{10}$ alongside the early effects of the baby boom (ibid.: 103) - teenagers were hence allowed to postpone their entry in the labour market. As a consequence, mid-1960s teenagers became Italy's first higher-educated generation, having a broader access to consumer goods and leisure, and turned out to be an even more interesting target market for the entertainment industry.

Accordingly, some teenager magazines were launched. Ciao amici (Hi Friends) was based in Milan, and imitated the French paper Salut les copains. The first issue appeared in December 1963, as a monthly publication; then in July 1965 it became bi-weekly; and subsequently weekly in March 1966. ${ }^{11}$ Big started its publication in 1965 as a weekly magazine (its tagline was "Il settimanale giovane": The Young Weekly). Big targeted a more mature readership than Ciao amici (high-school age), and sold between 400,000 and 500,000 copies (Giachetti 2002). In 1968 Big and Ciao amici merged into a new publication - Ciao Big, later Ciao 2001 - which became one of the most popular music magazines in the 1970s. Some radio shows followed the new trend. In October 1965 
Bandiera gialla (Yellow Flag) made its debut on the Rai (Italian public radio and television). It was broadcast live on Saturday afternoon, and featured hits and new singles by Italian and internationals artists. In March 1966, Radio Montecarlo started broadcasting in Italian. The cantautore Herbert Pagani hosted a show for young people.

As suggested by Alessandro Carrera (1980: 33), a community exists when it has its meeting place. Ciao amici and Big provided such a virtual space for teenagers to 'meet'. They worked as "interactive magazines" (Giachetti 2002). Both of them compiled a chart based on their readers' preferences. An important part of the two publications consisted of readers' pages, including advertisements for trading records and photographs and for corresponding with pen pals, as well as poems and short stories sent in by the readers. Advice columns offering sentimental and musical tips were given much space. Advice columnists like Luciano (Luciano Giacotto) at Ciao amici and Paola (Paola Dessy) at Big became widely known among young people. As recalled by Big's editor-in-chief Sergio Modugno (n.d.), an average of 2000 letters per week were addressed to Paola Dessy. Since Big maintained a fairly progressive editorial line, and targeted a more mature readership, Paola's advices also handled sex and relationship education, introducing a cautious yet open approach to issues which were still considered taboo by the conservative Italian society. In the first phase, explicit references to politics, and especially to political parties, were carefully avoided by both magazines (Giachetti 2002). Anyway, 'political' subjects were introduced in a fairly innovative way, notably by Big's editorial "Sveglia ragazzi!" (Wake Up, Kids!; Modugno n.d.); Big also supported pacifism and opposed militarism. Musicians were also writing articles or columns from their own perspective. The Italian-Belgian singer-songwriter Adamo, for instance, edited the mail column in Ciao amici.

Besides the virtual spaces provided by the readers' pages, the two magazines organized festivals and meetings for their supporters. Also, they created and maintained a network of their readers by encouraging them to gather together in associations and clubs. For example, Big promoted the Big Clan, and included in every issue stickers to cut out and paste on a 'Supporters Card'. Ciao amici established the so-called CIAC (Ciao Amici Club) all around Italy: at the end of 1966 they had about 28,000 members. The CIACs were given several pages in any issue for reporting on their activities. Meetings and changes between the different clubs were supported. Unsurprisingly, membership cards offered several discounts. When the Beatles announced their first Italian tour, Ciao amici provided a discount voucher for its readers. Merchandising lines and branded clothes were also launched, trying to reinforce the pride of belonging to a group of friends [see Figure 2].

The increasing success of Ciao amici and Big reflected the great innovations around Italian teenagers' music practices. Teenagers shared their records and listened to music together. Hence, music became the central element of a new way of gathering, as well as the cornerstone of a new ideology of the youth community. The field of a so-called musica nostra (music of our own ${ }^{12}$ ) was defined, which included 'young' genres such as the cantautori, the urlatori and especially beat and folk music. The tag musica nostra was subsequently widely used to talk about the music young people listened to. 


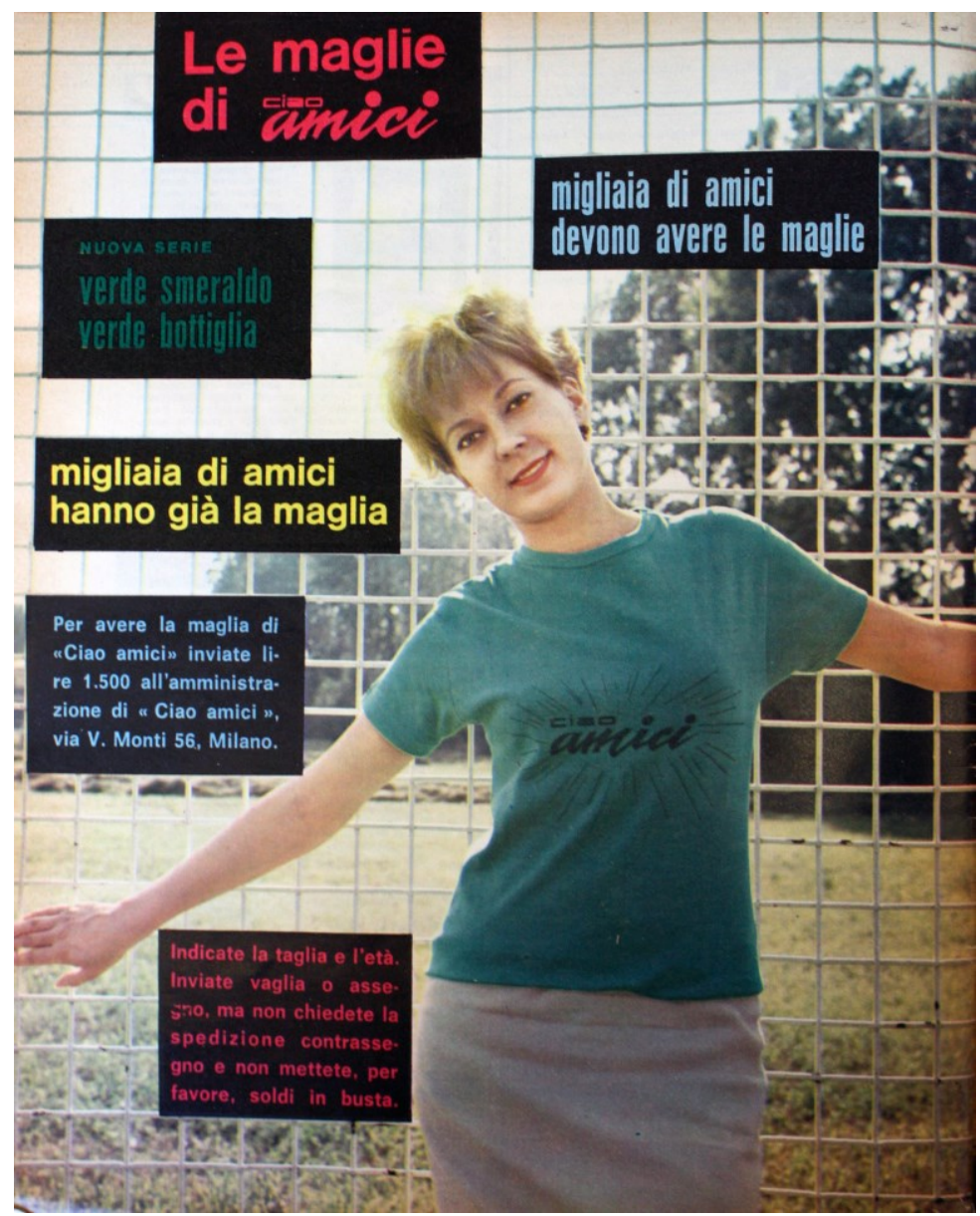

Figure 2: "Thousands of friends must have the sweater. Thousands of friends already have the sweater": commercial page from Ciao amici, 1964.

\section{Youth community and the musica nostra}

In January 1964, the prestigious newsweekly L'Europeo started a series of articles about the tastes and lifestyles of Italian teenagers. The ethnomusicologist and journalist Roberto Leydi (1964) took care of the first survey, which focused on musical habits - it is likely not coincidental that Ciao amici had started its publication a few weeks before. As a conclusion of his piece, Leydi stated his amazement at the strong relationship the young interviewees had with "their" songs:

Have we ever supposed - looking from the outside - that young people had such a deep identification with a specific kind of song, which they call - with ingenuous pride - 'ours'? (ibid.: 19) ${ }^{13}$

As far as we can gather from Leydi's article, young people had started to perceive themselves as a social group, a nationwide community with shared values and tastes. The key element in such a self-perception seems to be what Leydi defined as "pride" the sense of community had become a value in itself. The expression "musica "nostra" was also recorded and discussed by Umberto Eco in his key essay on mass culture Apocalittici e integrati, published in the same year (Eco 1964: 288).

What were the models of such an ideology of the community young people were constructing? Arguably, they could be found in Catholic associations, rather than in the school system. Italian Catholic youth associations have always had a prominent role in the control of young people's leisure. For this reason, they had been opposed by the Fascist party since the late 1920s, through the institution of the Opera Nazionale Balilla (later Gioventù Italiana del Littorio). After World War II and the dismantling of the Fascist youth organizations, the Roman Church regained its influence on teenagers' spare time. Furthermore, the Vatican had interests in the new-born Italian record industry, and 
owned a part of the Italian branch of RCA. Some evidence of the role Catholic associations had in shaping such an ideology of youth community can be found in the rhetoric of the teen pop press, as I discuss later.

Singer Adriano Celentano's example proved to be influential for the new youth community. Inspired by Frank Sinatra, he founded his own 'Rat Pack' (the 'Clan Celentano') in late 1961. The Clan was formally established as a record label, but Celentano had been running it as a family business, based on friendship and family values, together with some of his closest friends and relatives (Simonetta 1966). Celentano, in spite of his image as a young rebel, was a practising Catholic; between December 1963 and February 1964 he experienced an intense spiritual crisis, and some of his lyrics of that period deal with religion and a strong sense of community. In 1962 he had already hit the chart with his Italian version of Ben E. King's "Stand By Me", which became "Pregherò" ("I Will Pray", Clan 1962). In 1965 he released "Ciao ragazzi" ("Hi Kids", Clan 1965).

Hi kids, hi / l'd like to tell you that / that l'd like for me / big arms because / I could finally hug you all [...]

Hi kids, hi / you know that / that in the world there is / there is someone who prays for us / don't you cry because / there's someone who watch over us. ${ }^{14}$

The song attempted to imitate a gospel song, with a choir repeating each verse. Both the lyrics and the musical structure seem to reflect the ideology of the community outlined above. The title's similarity with Ciao amici seems not to be a coincidence. Yet again, it is definitely not accidental that Big gave the name 'Clan' to its group of supporters.

Around 1964 the musica nostra comprised the cantautori, the urlatori (or the former urlatori $^{15}$, such as Celentano) and the new teen idols, such as Gianni Morandi and Rita Pavone (see Eco 1964: 289 on Rita Pavone). Bands, with the exception of a picture of the Beatles, are not even mentioned by Leydi's article. The early teenage idols were solo artists.

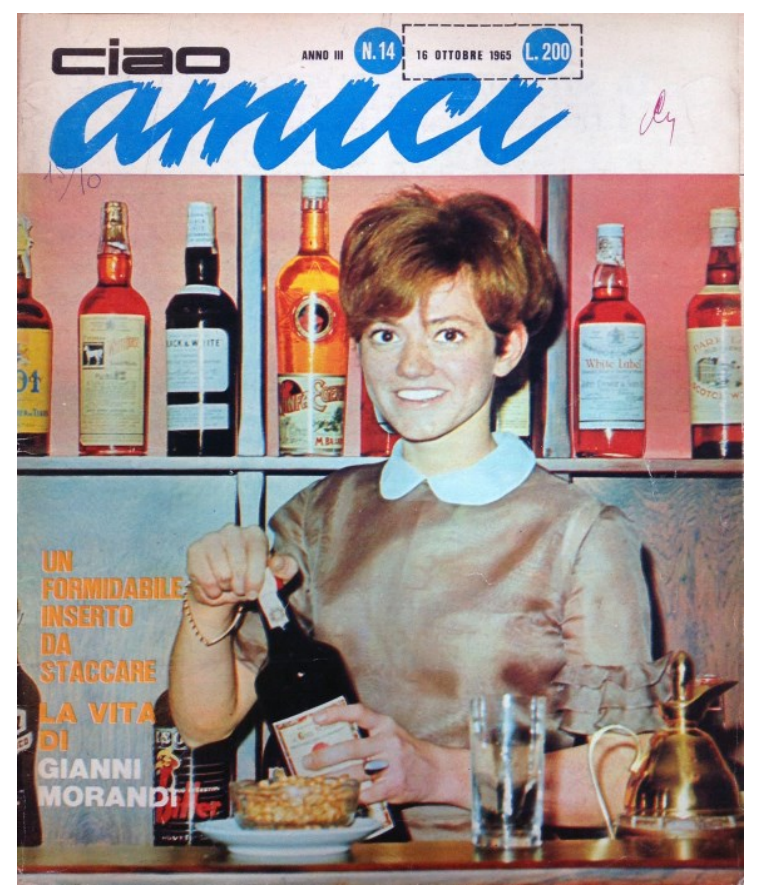

Figure 3: Rita Pavone on the cover of Ciao amici, 16 October 1965.

Bands were already diffused among Italian teenagers, but they developed as part of the recording business only after 1965. Indeed, excluding the Beatles, the first cover of Ciao amici featuring a band (The Rokes) appeared in December 1965. The British influence on Italian teenagers' musical practices became crucial after the Beatles toured 
Italy in June 1965. Their success was decisive in convincing the recording industry to invest in the Italian beat. Soon, starting a band became the hip thing to do, and some Italian groups started hitting the charts. The complessi (groups) introduced a new way of making music together, which was ideologically linked to the concept of musica nostra.

The public image of the bands, and the Beatles' above all, offered a social model of participation and friendship: band members wore the same outfits, shared the same microphone, did everything together and supported each other. Alessandro Carrera (1980: 51) recalls the symbolic value of the opening scene from the movie Help! by Richard Lester (1965) - the Beatles arrived at home, and entered four adjacent row houses that turned out to be one big shared home inside, where the four were living together. The sense of 'communion' the Beatles embodied worked as a frame for the development of the ideology of Italian youth community. It is no coincidence that their 1964 movie A Hard Day's Night had become, in its Italian version, Tutti per uno (One for All).

Teen pop magazines succeeded in building, or consolidating, their readership by supporting an ideology of the musica nostra based on fellowship, solidarity and a shared worldview. From 1966 onwards, the closer attention paid to Italian rather than international acts strengthened the national aspects of such an ideology. The youth community's pride and the definition of a music genre named musica nostra went side by side, reinforcing each other.

Connections between the youth community in Italy in the early 1960s and the later protests of 1968 and 1969 have yet to be proven. However, the same boys and girls who read Big and Ciao amici during their high school years were part of the generation that turned out to be the protagonists of the university students' demonstrations and riots. Lately, historians and sociologists of the same generation have flirted with the idea of the rise of a "class' of young people" (Gorgolini 2004: 223) in the 1960s, in part defined by shared music tastes (see also Dogliani 2003). Young people of the 1960 s seem to be lumped together as one generic 'youth class', rather than described in terms of different classes or subcultures. In particular, the Italian perspective seems to differ significantly from any account of music involving subcultures (which is "the dominant critical perspective in the UK", as noted by Atton 2009: 54). In any case, most studies underestimate the role of the teen pop press in the development of such an ideology of youth community, and its decisive influences on Italian culture.

\section{Teen pop press and its rhetoric: keywords and style}

This article argues that teen music publications and media consolidated a community ideology - and thus contributed to the construction of the concept of musica nostra mostly through the innovative language, style and rhetoric they introduced. Some recurring words of such a new way of talking about music have already been highlighted: clan, amici (friends), tutti (everybody), nostro/a (our), and so on. I will now briefly outline the main stylistic features of the prose used by the teen pop press, and its connection with the rise of the youth 'class consciousness' which I have hitherto described.

Together, Ciao amici and Big affirmed a new ground-breaking 'write-as-you-speak' journalistic style, full of colloquial expressions and occasionally youth slang. As noticed by Maurizio Dardano in his work on the language of Italian newspapers, journalistic discourse employs the imitation of spoken language as a populist strategy to convey a sense of "truth" (Dardano 1973: 254). Although this statement seems to be appropriate to describe the linguistic strategies of the teen pop press, linguists have paid rather less attention to the language of these publications. Most studies have debated the language of daily newspapers; likewise, several studies about the language of mass media have treated television, radio or comics, but have disregarded teen magazines. Also, most reports on youth languages have been devoted to post-1968 youth communities, rather than studying 1960 s teenagers. 
Among the many innovations in the language of the teen pop press, the subject positions assumed by the writer definitely stand out. Teen pop journalists were performing two different rhetorical functions at the same time: he/she presents himself/herself both as an older, wiser professional, and as a member, or at least a sympathizer, of the readers' community. The journalists were of course performing a social role through their writings, acting like peers, or sometimes like elder brothers or sisters. Writers pretended to be young, and sometimes denied to reveal their actual age. As the columnist Luciano answered to a young reader who was asking for his age:

If you have the (terrible) doubt that I am an old man, too bad for me then. It means that I write like an old man. (Luciano 1965) ${ }^{16}$

As an example, we can consider three articles from the first issue of Big: the editorial, the introduction to the advice column and a long article written (or, at least, signed by) the teen star Rita Pavone.

We will try, with good will, to understand you, forcing ourselves to be 'young' like you, trying to think like you, to understand your sudden sadnesses, your loneliness. Above all, we will try to discover why all these feelings can suddenly turn into an overwhelming wildness, into the craving for company, or for getting dazed. And, finally, we want to discover why happiness and serenity are not part of your way of living and thinking.

Therefore, we will cease to be journalists - or, at least, we'll do just the practical side of the job. You, friendly readers, must give us and tell us all you can to help us in this hard task we set for ourselves. You should show us the best way to create a perfect symbiosis between you and us. (Lazzari 1965) ${ }^{17}$

You should think of me as a big sis (a young and unknown one!), who understands you and loves you. (Metì 1965) ${ }^{18}$

Hello folks. Finally, good news for us! It seems that this new magazine Big has decided to throw itself headlong into our 'crazy' world of young folks. So, for a start, they popped me on the cover, and also here, just for an off-hand talk - but serious! - between us and about us. Good shot! (Pavone 1965) ${ }^{19}$

More often, journalists were acting as members of the community, offering their advice without sounding (too) paternalistic. The use of the first person plural, suggesting that the writer and the reader were part of the same community, was the crucial feature of the style of both Ciao amici and Big. The journalists addressed the readers directly, calling them 'friends' (especially in Ciao amici), 'gente' (folks) or 'ragazzi' (guys) to establish an immediate connection. Several fixed formulae or catch-phrases were used. The colloquial style (which newspapers and magazines normally use) was thus transformed into a distinctive form of written language, a youth language with its own linguistic conventions. As a consequence of these inclusive rhetorical strategies, the youth community defined itself by excluding some others. Obviously, the world of adults was the main target. Nonetheless, the opposition to adults and parents was soon transformed into a challenge to the music establishment. The recording industry was accused of not respecting young people's tastes, and thus harshly bashed and mocked:

In Venice, why did they present personalities that don't matter to us? When will the organizers of these events realise that it's us who buy records? Why are the friends not represented by anyone in the panels of judges? [...] Gianni Ravera [the organizer of the festival here criticised] used to be a singer, at least ten years ago. He wasn't that bad: among the plethora of those warbling singers, with their one-minute-minimum finale, he was the guy who tried to impose the rhythm. His only misfortune was that success came alongside a merciless baldness. Can you picture it, my friends? A sturdy guy, with a few hairs on his head, reaching towards you and pleading: 'My love please come back to me'. Wouldn't he be ridiculous! Ravera had this impression, too, so he decided to change jobs. [...] Surely, he was the first to understand that 'young people', or 'the friends' we should say, in other words 'we', are a big audience. An important audience, which represents at least the sixty or seventy percent of the annual income of pop music. (Giampiero S. 1964: 26). ${ }^{20}$ 
The rhetoric and the lexicon are also modelled on those used by the readers, mail columns providing valuable examples. Letters, advice and articles dealing with the pride of belonging to the magazine's community were strongly encouraged. A model of this rhetoric may be found in the language of Catholic associations, as evidenced in this letter sent to Ciao amici:

Believe me, I don't have words to express all my true appreciation for the incomparable communion which is set between us, young people, and the outside world, thanks to the magazine Ciao amici. I really feel like I am a friend of yours, my dear Luciano, and of all those who collaborate on this. (Fernando P. 1964: 5, emphasis mine) $)^{21}$

As part of a reader-friendly strategy conveying a strong feeling of participation, readers were often informed about the activities of the editorial staff. The office was habitually described as a thrilling place, where famous singers and bands were passing by. Many articles explained how the editorial job was done, and described the difficulties (and contentment) in attending and organizing events. For example, Ciao amici opened its coverage of the 1965 Sanremo Festival with a long editorial lamenting the costs of the trip:

So, after the end of the Festival, we met in the hall of our hotel in Sanremo and we rapidly made a balance sheet [...] In conclusion: a Sanremo Festival (three days long) costs between one-hundred and one-hundred fifty thousand lire.

Then Luciano asked if we were going crazy. We all agreed that only millionaires, sheiks and maybe some lucky businessmen could afford it. Anyway, only people who are much older than thirty. Indeed, there were very few young people in Sanremo. (Ciao amici 1965) ${ }^{22}$

Unsurprisingly, some new radio broadcasts for teenagers imitated the youthful style of the teen pop press, and succeeded in spreading the community feelings to their vast audience. Indeed, the same music professionals were often involved in both media. As an example, the popular radio show Bandiera gialla was hosted by Renzo Arbore with Gianni Boncompagni, who also held a column in Big. The opening announcement of the broadcast, delivered by a radio speaker, read as follows:

All the over eighteen-year olds! All the over eighteen-year olds!

This program is strictly reserved for young people - I repeat - for young people. All the others are kindly asked to turn off the radio, or switch to another station. ${ }^{23}$

\section{Building boundaries: 'musica nostra' as an aesthetic concept}

I will now outline how the ideology of youth community and the related concept of musica nostra promoted by the teen pop press were connected to aesthetic values.

The aesthetic of music Ciao amici and Big established was mainly based on popularity. Commercial value overlapped with aesthetic value. Teen magazines usually praised as 'good' what was popular and ignored what was not. Unknown artists were launched by predicting their future fame, or simply stating that they were already popular in other countries. Advertisements seemed to work the same way [see Figure 4]. 


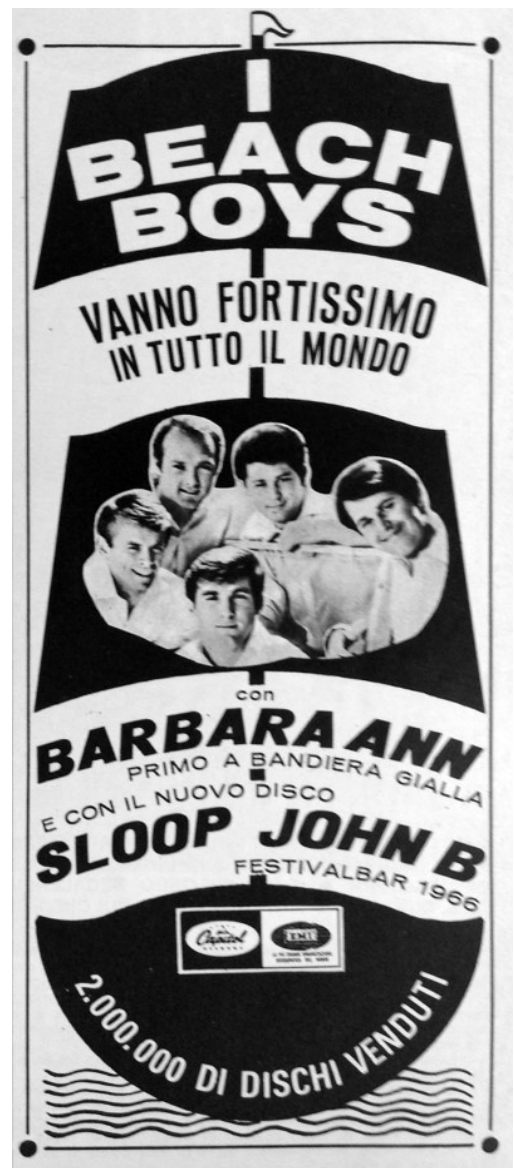

Figure 4: "The Beach Boys are flying off the shelves $\mathbf{- 2 . 0 0 0 . 0 0 0}$ of records sold". Advertisement from Ciao amici, 1966.

From a 'rock-centric' viewpoint, an ideology of music criticism has emerged since the beginning of the 'golden age' of popular music journalism, in the late 1960s and early 1970s - authenticity stood out as the main feature of an account of creativity largely based on the Romantic concept of the artistic genius: "[r]ock critics have had to establish their own version of auteur theory" (Frith 1978: 201). In Italy, an account of the "song as art' has been present in the popular music press since the early 1960s, after the rise of the cantautori. Cantautori were interpreted through an ideology of authorship, and thus of authenticity (Tomatis 2013: 88). Nonetheless, in their first phase, both Ciao amici and Big did not provide a critical perspective on the artists they covered. Some other mass music papers did: Sorrisi e canzoni - possibly the most popular magazine between the 1950s and 1960s - had published record reviews since the 1950s. Moreover, reviews were occasionally very harsh. Yet, teen pop magazines were not interested in slating poor records. Just like English music papers between the 1950s and 1960s, they "gave kids what they want" (as stated by Alan Smith of NME, quoted in Frith 1983: 167). Their editorial policy was that if it is popular among young readers, then it must be good. Or as Ciao amici's advice columnist Luciano stated, answering a young reader:

You see: that's the way Ciao amici makes its selection: it's only interested in friends. The others, we don't care about. They don't exist. (Luciano 1964)24

The field of 'what is popular among friends' was thus taken as the basis for an aesthetic conception of music grounded on community values. From a diachronic perspective, the teen pop press had been slowly introducing a critical view based on the ideology of musica nostra as a genre. Yet again, an authenticity-based aesthetic was set. As noticed by Richard Middleton (2006: 200), authenticity "is taken to mark out the genuine from the counterfeit, the honest from the false, the original from the copy, roots from surface". Music discourses often articulate aesthetic questions into binary 
opposition. Ciao amici and Big set the boundaries between 'music' and 'our music'. What was part of our music was authentic, and thus valuable. What was not, was not worth anyone's attention.

Big was the first to transform the ideology of the musica nostra into a true critical perspective. For instance, each week two records were presented and compared. The two headers read: "We like" / "We do not like". The dislikes usually featured old fashioned 'adult' singers, such as Claudio Villa. Thus, an aesthetic perspective was not presented as the personal opinion of an authoritative critic - 'we' meant both the editorial staff and the readers' community. In this way, the system of values was judged and authenticated by the community itself, and became absolute, at least from the readers' perspective.

This peculiar 'aesthetic of popularity' came to an end around 1967. A watershed in the history of Italian popular music occurred when the cantautore Luigi Tenco was excluded from the final of the 1967 Sanremo Festival and committed suicide "as an act of protest" against the music system, as he wrote in his farewell message. Tenco, though he was less popular than other cantautori, was strongly supported by Big and praised as an innovator. His death affected the way young people and the youth press considered 'their' music. The teen pop press news coverage from the Festival demonstrates how Tenco's death was experienced by the mid-1960s youth community as a sort of loss of innocence. For example, a title read:

Do you still trust the Festival? It's like believing in the Easter Bunny! (Giovetti 1967) ${ }^{25}$

Some scholars have considered Tenco's death as a crucial moment in the definition of an aesthetic of popular music based on authorship, which later proved to be decisive in establishing the canzone d'autore ('auteur song') genre (Santoro 2006 and 2010; Tomatis 2013). As noticed by Santoro, the left-wing press (but also youth magazines) gave the suicide a sociological dimension. Suddenly, youth music became a serious thing, something which was worth dying for. The music industry - that 'evil' system which had 'killed' Tenco - entered as a leading actor in the mediation on what was authentic (and thus valuable) and what was not. From a Bourdieuan perspective, Italian canzone had entered the field of "cultural goods production [...] in which the positive sanctions of the market are indifferent or even negative" (Bourdieu 1998: 110). Tenco's tragedy provided the "cognitive, emotional and symbolic resources" (Santoro 2010: 12) to reframe the conventions of youth music and its rhetoric. Tenco's interpretive frame as a "victim of the system" was widely compatible with both leftist ${ }^{26}$ and social Catholic ideologies, and eventually started a process of "sacralization" of song culture (ibid.). This happened to be the turning point in the crystallization of an auteur-based aesthetic of the Italian canzone, which still affects the way Italian music communities classify and evaluate music. Also, a different way of writing about music developed, which praised originality and technical skill rather than youthfulness as a way of valuing music; more magazines were founded; and Big and Ciao amici merged into a new magazine in 1968, Ciao 2001, which dismissed some of the magazines' youthful connotations. The tag musica nostra was soon abandoned, and the idea of a shared 'music of our own' lost its force. Yet several traces of the rhetoric of the teen pop press (including Catholic hints) can be found in the style of the early writings about the canzone d'autore (Tomatis 2013).

\section{Conclusion}

In my analysis of Italian youth music and its genres between 1964 and 1967, I have followed the framework provided by three questions: 1) how people, or specific communities, classified music in a given period and place, and which tags they used; 2) which kind of language different music communities used to talk about different genres; and 3) which ideologies structured music values and meanings, and how music aesthetics developed accordingly, in relation to genres. Some conclusions can be drawn.

Firstly, in the mid-1960s, the Italian youth community used several tags to classify music. In some cases, international genres were 'translated' into Italian, and their 
meanings re-negotiated (as for 'beat' and 'folk'). Between approximately 1964 and 1967, the tag musica nostra was used by the teen pop press to define the music and the genres young people were listening to. New teen idols, as well as genres such as the cantautori, the urlatori and, later, beat and folk, were part of the musica nostra genre. Teen pop publications played a major role in establishing a strong sense of community among young people, and in popularising the concept of musica nostra as a 'generational flag'.

Secondly, such an ideology of youth community was established mainly through the innovative language, style and rhetoric introduced by the teen pop press, and later popularised by radio broadcasts. The style of the teen pop press included: inclusive rhetorical strategies, such as the use of first person plural; the use of recurring words such as clan, amici (friends), tutti (everybody), nostro/a (our), etc.; catch-phrases and fixed formulae; colloquial expressions and youth slang. The model for both the ideology of youth community and these inclusive strategies can be probably found in Catholic associations.

Thirdly, between 1964 and 1967, Ciao amici and Big proposed an aesthetic of popular music which praised popularity among the youth community as a form of authenticity. Boundaries were set between the 'music' (i.e. adults' music) and 'our music'. What was part of 'our music' was authentic, and thus valuable. Such an ideology of the musica nostra affected the way Italian popular music was perceived and interpreted by young people.

As popular music scholars approaching the popular music of the past, we must face historiographical issues. As noted by Fabbri (2013a), music magazines - and especially the teen pop press - "didn't say the truth". So, why should we use them? And how? While attempting to reconstruct a historical phenomenon "in its contemporary understanding" (Altman 2004: 18), we must ask which sources can be trusted and, especially, "how can the commonsense or ideology of a certain period, genre, or scene, be reconstructed, by working on historical documents?" (Fabbri 2013a).

The goal of this paper was to reconstruct such a "commonsense", or "ideology", within the limit of a case study. Nevertheless, I claim the methodology here presented can be profitably applied to different periods and larger music communities, all around the world. Discourses about music can tell us much about the way music communities classified and evaluated music. Music genres are established, named and negotiated in their meanings through interpretive processes, by different actors: music industry, musicians, critics, fans, etc. All these processes constitute the 'discourses' about music, and their traces can be found in the music press, as the place where different interests and positions met and collided.

From this perspective, the music press - mass magazines and teen pop press rather than underground publications - can provide an irreplaceable source of data for studying the popular music of the past. Further research on popular music journalism should critically engage with the issues raised here as a way of understanding how communities gave meaning to 'their' music.

\section{Endnotes}

1 Lindberg et al. (2005: 13) notice, in regard to Fish's idea, that "the critic's position cannot be reduced to any purely representative role [because] it always contains an 'excess' of subjectivity". Yet, in Fish's perspective there is no "representative role", neither subjectivity nor objectivity. An interpretive community "is not objective because as a bundle of interests, of particular purposes and goals, its perspective is interested rather than neutral" (Fish 1980: 14); by the same reasoning, "the meaning and texts produced by an interpretive community are not subjective because they do not 
proceed from an isolated individual but from a public and conventional point of view" (ibid.). I therefore assume that such a concept is still useful for interpretive purposes.

2 See, for instance, Looseley 2003 on French popular music.

${ }^{3}$ As an example we can consider the differences between the concepts of cantautore and singer-songwriter: see Tomatis 2010 and 2013.

4 For an overview of authenticity in popular music studies see Weisethaunet and Lindberg 2010.

${ }^{5}$ Jones 2002 provides a valuable overview of studies of the popular music press.

${ }^{6}$ All translations are mine. I provide the original quotations in the notes: [...] questa musica americana ci si è rovesciata addosso tutta insieme, senza preavvisi e senza discriminanti. Ci mancavano gli strumenti per distinguere, all'interno del rock, i diversi filoni e le diverse tradizioni: non solo era musica del tutto estranea al nostro retroterra culturale (e per questo ci attirava), ma ci perveniva già mescolata e confezionata, impedendoci di ricostruirne l'evoluzione e la vicenda storica.

${ }^{7}$ On Italian beat (the so-called 'bitt') see Fabbri 2013b.

8 'Beat', tecnicamente parlando, è tutta la musica con una ritmica in 'battere'. Sono beat il rhythm \& blues, il rock, il folk-rock e cosi via. In Italia, nell'accezione comune, beat significa musica inglese, 'english sound'.

${ }^{9}$ II musichiere was the Italian version of the NBC TV show Name That Tune.

10 The reform of secondary school (scuola media unica) dated 1962.

${ }^{11}$ My research is limited to the two most popular teen pop magazines of the 1960s, Ciao amici and Big. Also, Giovani (later Qui giovani) — published since 1966 and based in Milan - and Tuttamusica were slightly popular among teenagers (Stampa Musicale n.d.; Giachetti 2002).

12 In spoken Italian, the possessive adjective usually comes before the noun (la nostra musica rather than la musica nostra). The post-position of the possessive adjective adds emphasis (D'Achille 2003:147).

13 [...] avremmo sospettato, osservando soltanto dal di fuori il comportamento dei giovani, che la identificazione fra loro e la canzone di un certo tipo (quella che chiamano, con ingenuo orgoglio, la 'nostra' canzone) fosse cosi profonda?

${ }_{14}$ Ciao ragazzi ciao / vorrei dirvi che / che vorrei per me / grandi braccia perché / finalmente potrei / abbracciare tutti voi [...]

Ciao ragazzi ciao / voi sapete che / che nel mondo c'è / c'è chi prega per noi / non piangete perché / c'è chi veglia su di noi.

15 By that time, the term urlatore was already out of vogue.

16 Se tu hai il dubbio (atroce) che io sia vecchio, peggio per me, vuol dire che scrivo come un vecchio.

17 Noi cercheremo con ogni buona volontà di comprendervi, sforzandoci di essere 'giovani' come voi, di pensare come voi, di capire le vostre improvvise tristezze, la vostra solitudine, e soprattutto di scoprire perché tali stati d'animo si trasformino all'improvviso in travolgenti sfrenatezze, nel bisogno di cercare molta compagnia, nella necessità di stordirsi, e, infine, perché sia lontana dal vostro modo di vivere e di pensare la serenità e la letizia. In questo senso noi cesseremo di fare i giornalisti, o, perlomeno, lo faremo soltanto per la parte tecnica. Voi, amici lettori, dovrete darci e dirci tutto, aiutandoci in questo difficile compito che ci siamo imposti, suggerendoci problemi che cercheremo di risolvere insieme, indicandoci la via migliore per creare fra voi e noi una simbiosi perfetta.

18 Pensate che io sia una sorellona maggiore (ma giovane e sconosciuta!) che vi capisce, che vi vuole bene. 
19 Salve gente, finalmente una buona notizia per noi! Pare che questo nuovo giornale Big voglia buttarsi a pesce nel nostro 'pazzo' mondo di giovani e, tanto per cominciare, mi hanno catapultato in copertina ed anche qui per chiacchierare alla buona, ma seriamente, tra di noi e su di noi. Bel colpo!

20 Perché a Venezia sono stati presentati personaggi che non ci interessano? Quando gli organizzatori di queste manifestazioni si renderanno conto che siamo noi gli acquirenti dei dischi? Perché nelle varie giurie non ci sono mai rappresentanti degli amici? [...] Quando Gianni Ravera cantava (almeno una decina di anni fa) non era niente male: fra la pletora dei gorgheggiatori con finale minimo da un minuto era quello che aveva cercato di imporre il ritmo. Ebbe solo una grande disgrazia: il successo gli arrivò di pari passo ad una spietata calvizie. Amici, lo immaginate un tipo, abbastanza robusto, con qualche pelo in testa, che allungando le braccia verso di voi invoca: - Amore, torna ti prego, torna - ? E un po' ridicolo, no? Anche Ravera, allora, ebbe questa impressione e decise di cambiar mestiere. [...] Senza dubbio è il primo che abbia intuito che $i$ 'giovani', tanto per intenderci 'gli amici' insomma 'noi' siamo un grande pubblico. Un pubblico importante perché nel gettito annuale della musica leggera rappresentiamo perlomeno il sessanta o settanta per cento.

21 Credimi, non ho parole per esprimere tutto il mio più sincero consenso per la ineguagliabile comunione che con la rivista Ciao amici viene a stabilirsi tra noi giovani e tutto il mondo esteriore. Sinceramente ora mi sento veramente amico di te, caro Luciano, e di tutti coloro che collaborano alla realizzazione di questo lavoro.

22 Dunque, a festival concluso, ci siamo trovati nella hall del nostro albergo a Sanremo e abbiamo fatto un rapido bilancio [...] Conclusione: un Festival di Sanremo (durata tre giorni) costa dalle cento alle centocinquanta mila lire. Allora Luciano ha detto se per caso non eravamo sulla strada della follia e tutti abbiamo convenuto che, con questi prezzi, il Festival se lo possono permettere soltanto gli armatori, gli sceicchi e qualche industriale particolarmente fortunati. Tutta gente, comunque, che ha ampiamente superato il limite dei trent'anni. Infatti, I giovani, a Sanremo, erano veramente pochini.

${ }^{23}$ A tutti i maggiori degli anni diciotto, a tutti i maggiori degli anni diciotto, questo programma è rigorosamente riservato ai giovanissimi, ripeto, ai giovanissimi, tutti gli altri sono pregati quindi di spegnere la radio o sintonizzarsi su altra stazione...

24 Vedi, Ciao amici usa proprio questo metodo di selezione: si occupa soltanto degli amici. Gli altri, non ci interessano, non esistono.

25 Credete ancora al festival? È come credere alla Befana!

${ }^{26}$ Some scholars have connected Tenco's suicide to the 1968 student demonstrations (see Borgna and Dessì 1977).

\section{References}

Agostini, R. 2007. The Italian Canzone and the Sanremo Festival: Change and

Continuity in Italian Mainstream Pop of the 1960s. Popular Music 26 (3): 389-408.

Altman, R. 2004. Silent Film Sound. New York: Columbia University Press.

Atton, C. 2009. Writing About Listening: Alternative Discourses in Rock Journalism. Popular Music 28 (1): 53-67.

Big. 1967. Oggetto: il beat, Big, year 3, no. 1, 4 January: 46-48.

Borgna, G. and Dessì, S. 1977. C'era una volta una gatta. I cantautori degli anni '60, Rome: Savelli.

Bourdieu, P. 1998. Practical Reason: On the Theory of Action. Stanford, CA: Stanford University Press. 
Bratus, A. 2012. Scene through the Press: Rock Music and Underground Papers in London, 1966-73. Twentieth-Century Music 8 (2): 227-252. Cambridge: Cambridge University Press.

Carrera, A. 1980. Musica e pubblico giovanile. L'evoluzione del gusto musicale dagli anni Sessanta ad oggi, Milan: Feltrinelli.

Ciao Amici. 1965. La nostra festa - La festa degli amici, Ciao amici, year 2, no. 2, January: 17.

D’Achille, P. 2003. L'italiano contemporaneo. Bologna: II Mulino.

Dardano, M. 1973. Il linguaggio dei giornali italiani. Bari: Laterza.

Dogliani, P. 2003. Storia dei giovani. Milan: Bruno Mondadori.

Eco, U. 1964. Apocalittici e integrati. Milan: Bompiani.

Fabbri, F. -

1982. A Theory of Musical Genres: Two Applications. In David Horn and Philip Tagg Eds. Popular Music Perspectives. Göteborg and Exeter: International Association for the Study of Popular Music: 52-81.

2009. Around the Clock. Una breve storia della popular music. Turin: Utet.

2012. How Genres Are Born, Change, Die: Conventions, Communities and Diachronic Processes. In Stan Hawkins Ed.Critical Musicological Reflections. Aldershot: Ashgate: 179-191.

2013a. What do we mean by 'empirical'? Paper presented at IASPM's 17th International Conference on Popular Music Studies, Gijón, Spain, 24-28 June 2013. http://www.academia.edu/4265340/What do we mean by empirical; Accessed: 21 September 2013.

2013b. And the Bitt Went On. In Franco Fabbri and Goffredo Plastino Eds. Made in Italy: Studies in Italian Popular Music. London: Routledge: 41-55.

Feld, S. 1984. Communication, Music, and Speech About Music. Yearbook for Traditional Music 16: 1-18.

Fernando P. 1964. Posta. Ciao amici, year 2, no. 8, August: 5.

Fish, S. 1980. Is There A Text in this Class? The Authority of Interpretive Communication. New York: Cambridge University Press.

Frith, S. -

1978. Sociology of Rock. London: Constable.

1983 Sound Effects: Youth, Leisure, and the Politics of Rock ' $n$ ' Roll. New York:

Pantheon Books. Second edition.

Giachetti, D. 2002. Tre riviste per i 'ragazzi tristi' degli anni sessanta, L'impegno, year 12, no. 2, December.

Giampiero S. 1964. Qualcosa non funziona. In Ciao amici, year 2, no. 9, September: 26-27.

Giovetti, C. 1967. Credete ancora al Festival? È come credere alla Befana!, Big, year 3, no. 6, 8 February: 48-49.

Gorgolini, L. 2004. I consumi. In Paolo Sorcinelli and Angelo Varni Eds. I/ secolo dei giovani. Rome: Donzelli: 213-254.

Gudmundsson, G., Lindberg, U., Michelsen, M., and Weisethaunet, H. 2002. Brit crit: Turning Points in British Rock Criticism, 1960-1990. In Steve Jones Ed. Pop Music and the Press. Philadelphia: Temple University: 41-64.

Jones, S. Ed. 2002. Pop Music and the Press. Philadelphia: Temple University Press.

Kaufman S. K. 2011. Musical Communities: Rethinking the Collective in Music. Journal of the American Musicological Society 64 (2): 349-390.

Lazzari, I. 1965. Editoriale, Big, year 1, no. 1, 11 June: 3. 
Leydi, R. 1964. Perché gli urlatori, L'Europeo, 12 January 1964: 14-19.

Lindberg, U.; Gudmundsson, G.; Michelsen, M. and Weisenthaunet, H. 2005. Rock Criticism from the Beginning. New York: Peter Lang.

Looseley, D. 2003. Popular Music in Contemporary France. Authenticity, Politics, Debate. Oxford and New York: Berg.

Luciano -

1964. Posta. Ciao amici, year 2, no. 8, August: 5.

1965. Posta. Ciao amici, year 3, no. 1, January: 6.

Metì. 1965. Busta rosa busta azzurra, Big, year 1, no. 1, 11 June: 3.

Middleton, R. 2006. Voicing the Popular. On the Subjects in Popular Music. New York: Routledge.

Modugno, S. (n.d.) lo testimone oculare, www.sopi.it/Anni60/1965/testimoneoculare1.htm Accessed: 5 April 2013.

Pavone, R. 1965. Non è vero che il mondo è dei giovani, Big, year 1, no. 1, 11 June: 24-27.

Portelli, A. 1978. Elvis è una tigre di carta (ma sempre una tigre). In Carpitella, Diego; Castaldo, Gino; Pintor, Giaime; Portelli, Alessandro and Straniero, Michele L., La musica in Italia. L'ideologia, la cultura, le vicende del jazz, del rock, del pop, della canzonetta, della musica popolare dal dopoguerra a oggi, Rome: Savelli: 9-68.

Profane, B. (n.d.) Intervista a Max Stefani, http://www.musicalnews.com/articolo.php?codice=32\&sz=1 Accessed: 5 April 2013.

Rapini, A. 2004. Denaro e lavoro. In Paolo Sorcinelli and Angelo Varni Eds. II secolo dei giovani. Rome: Donzelli: 81-112.

Rotondi, G. 2010. Trapassati alla storia: Piero Vivarelli, Focus Storia, no. 49, November: 26.

Santoro, Marco -

2006. The Tenco Effect. Suicide, San Remo, and the Social Construction of the Canzone d'Autore. Journal of Modern Italian Studies 11 (3): 342-366.

2010. Effetto Tenco. Genealogia della canzone d'autore. Bologna: II Mulino.

Seeger, C. 1977. Studies in Musicology 1935-1975. Berkeley: University of California Press.

Simonetta, U. 1966. Celentano. Milan: Longanesi.

Sorcinelli, P. and Varni, A. Eds. 2004. Il secolo dei giovani. Le nuove generazioni e la storia del Novecento. Rome: Donzelli.

Stampa Musicale (n.d.) Riviste anni 60, http://stampamusicale.altervista.org/Riviste 60/Riviste\%2060.htm; Accessed: 5 April 2013.

Tomatis, J. -

2010. 'Vorrei trovar parole nuove'. II neologismo 'cantautore' e l'ideologia dei generi musicali nella canzone italiana degli anni Sessanta. IASPM Journal 1 (2): 1-23.

2013. A Portrait of the Author as an Artist: Ideology, Authenticity, and Stylization in the Canzone d'Autore. In Franco Fabbri and Goffredo Plastino Eds. Made in Italy: Studies in Italian Popular Music. London: Routledge: 87-99.

Toynbee, J. 1993. Policing Bohemia, Pinning Up Grunge: The Music Press and Generic Change in British Pop and Rock. Popular Music 12 (3): 289-300.

Weisethaunet, H. and Lindberg, U. 2010. Authenticity Revisited: The Rock Critic and the Changing Real. Popular Music and Society 33(4): 465-85. 


\section{Discography}

Celentano, Adriano --

1962. Pregherò / Pasticcio in paradiso, Clan ACC 24005

1965. Ciao ragazzi / Chi ce l'ha con me, Clan ACC 24022

I Nomadi. 1966. Noi non ci saremo / Un riparo per noi, Columbia SCMQ 7021 